\title{
Corporate communication and strategic management: history, operational concept and integration
}

\author{
Bahtiar Mohamad \& Hassan Abu Bakar \\ Universiti Utara Malaysia, Sintok, Malaysia
}

\begin{abstract}
There are divergent views within the literature as to what is meant by corporate communication. In this article, the authors discuss three main areas, which covered the history, the operational concepts and last the integration of corporate communication with strategic management. Currently, international companies are increasingly emphasizing their corporate communication in trying to project a favorable image and reputation that in line with the company's strategic management. Ongoing trends such as globalization a strategic corporate communication have accelerated the need to coordinate and harmonize companies' disparate global identities and images. This paper seeks to establish the rationale behind the strategic corporate communication program, while looking at issues pertaining to it operational concept, and integration with the strategic management. The wide variety of literature relating to history, concept and integration of corporate communication will be discuses, mainly from a strategic management perspective.
\end{abstract}

Keywords: corporate communication, strategic management, integration

\section{INTRODUCTION}

The literature on corporate communication dates back to 1970's (Yamauchi 2001). However, at that time, corporate communication was known as corporate public relations and was the responsible of the public relations department of the organization. Earlier writings on corporate communication were from journalism, and it focused more on persuasive messages to create mutual understanding between organizations and their respective stakeholders (Grunig \& Hunt 1984). A two way symmetrical model is widely practiced by organizations and corporate PR practitioners more concerned with stakeholders' feedback. For instance, topic studies included the role of corporate communication in media relations, crisis communication, issues management, community relations and public affairs. Subsequently, the research on corporate communication expanded dramatically in the early 21 st century, and covered various issues across multi disciplines including strategic management, marketing, communication and investor relations (Argenti 2000).

As iterated earlier on, the concept of corporate communication is still under developed and needs more attention (van Riel 1995, Varey 1997). There exist several unsolved issues in previous research.
For example, the issues measurement concepts of corporate communication (Macnamara 2006) are still not well understood. In addition to that, issues like the relationship between corporate communications and strategic management (Goodman 2000, Welch \& Jackson 2007) are still very much unclear.

This paper is a review of literature on the concept, history and integration of corporate communication with strategic management. It examines existent studies on the area of communication, strategic management, marketing, public relations and sociology. The paper begins with the discussion about different definitions and characteristics of the corporate communication concept. Past studies on the history and integration will then be reviewed.

\section{HISTORY OF CORPORATE COMMUNICATION}

'Corporate' originated from Latin corpus meaning to complete, entire or total entities of the organization, while 'communication' is from the word 'communicare'. In Latin, the word means to impart, share, or make common. Therefore, 'corporate communication' can be defined as a total communication of the organization, and it integrates different messages of 
organizations under one banner (Christensen et al. 2007).

Yamauchi (2001) believes the term 'corporate communication' came to the attention of the general public more than 30 years ago when the US business magazine Fortune held its first annual Corporate Communication seminar in 1972. However, throughout the 20th century, the field of corporate communication has been developed in schools of communication and journalism and is categorized as public relations or public affairs (van Riel 1995). In the early years, corporate communication practitioners worked more on tactical communications with the media to create a good image for organizations. In the early 1970's, the corporate world changed and demand from internal and external stakeholders of companies became more sophisticated and complex. The organizations required more than the simple internal public relations (PR) function supplemented by the PR consultant firm. For example, public relations practitioners faced great challenges to deal with a 'new generation' of stakeholders. Consequently, the top management of many organizations started looking at communication as more than just 'communication' to the stakeholder. According to Argenti (1996) and Cornelissen (2008), this is the commencement of the new corporate communication practices and function.

Historically, people from business backgrounds started to take over the role of corporate communication because of the inability of the public relations practitioner to communicate the 'business substances' to the organization stakeholder. For example, research by Wright (1997) indicates only 42 percents public relations practitioners possessed an adequate knowledge of business. Realizing the importance of corporate communication in business, many business schools began to focus on it, and make it as a subset of management communication (Argenti 1996). Many schools of communication argue that they are the appropriate incubator for the development of theory and practice in the field of corporate communication. However, the debate on this matter continued over which field is best equipped to handle corporate communication development. Argenti (1996) firmly argued that business schools are the most suitable places for the discipline because the function of corporate communication in the organizations is the same as others such as marketing, finance, production and human resource management. Therefore, the existence of corporate communication is vital for most organizations and should be put under the business administration domain. Furthermore, Argenti (1996) believed that corporate communication has evolved within the business environment more rapidly and much more systematically.

Although, public relations scholars and practitioners were continuously interested in the corporate communication, they failed to convince the senior managers on the importance of their role in decision making (Wright 1997). This is largely due to the inability of many corporate public relations managers to escalate beyond the level of the communication technicians. This has led a lack of acceptance among the corporate leaders on the role of public relations as strategic counselors for the organization. This development formed the necessity for business schools to prepare their own professionals who understand and communicate business messages with other managers. In some extreme cases, few big companies have even removed the top corporate public relations positions, and appointed people from other fields as senior communication officers.

Currently, many managers in multinational companies come from very traditional oriented backgrounds such as engineering, accounting, finance, production, sales or marketing (Argenti 1996). Their communication skills depend on abilities that they might have gained from tertiary education, school or years of experience. These old-style managers welcomed a professional communicator to help and guide them to communicate better in their organization. Consequently these situations made the field of corporate communication more important for the organizations (van Riel 1995).

\section{DEFINING CORPORATE COMMUNICATION}

In general, corporate communication is a management tool which surfaced in response to the increasing concern on the complex communication processes within corporate organizations (Argenti 1998). The complexity of organization growth is commonly synchronized and is increasingly implicated by technology advancement and modern organizational structure.

The definition of corporate communication has been discussed by many scholars and can be seen from different perspectives. Based on Cornelissen (2008), Van Riel \& Fombrum (2007), and Goodman (2000), three salient characteristics of corporate communication can be delineated as follows:

Management instruments or tools: The concept of management in corporate communication is salient to many organizations (van Riel 1995, Cornelissen 2008). The management function can be seen in corporate communication in terms of planning, controlling, organizing and coordinating the communica- 
tion's message to internal and external stakeholders of the organizations.

Internal and external communication: According to Varey (1998), internal communication is the sharing of messages within the transformation process of the enterprise, and it includes giving and taking orders and directives, generation, dissemination and interpretation of performance data and task instruction. The external communication messages are shared between members and representative of the environment in the form of promotional messages via mass communication media and inward in the form of market information. The medium of communication is dependent on who is the receiver (stakeholder). Media or channel of communication used by organization to transfer organizational messages to stakeholder might vary: This may include: Internal mail, intranet, face to face, circular or bulletin. However, to attend to various numbers of external stakeholder, mass communications instruments such as electronic media (television and radio), print media (newspaper and magazine) and new media (internet) are the most influential channels used to persuade their stakeholders.

Stakeholders or audiences: The receiver of the communication's message in the corporate organization is their stakeholders. In corporate communication, stakeholders can be divided into two: Internal or external stakeholders (van Riel 1995, Goodman 2000, Cornelissen 2008). Employees and the top management of the organization can be considered as internal stakeholders, while external stakeholders may include media, nongovernmental organizations (NGO), government agencies, customers and competitors.

Taking into account the prevailing definitions and important characteristics of corporate communication, this study defines corporate communication as a management of the organizational perception (Schmidt 1995). The perception of audiences or stakeholder can be influenced from all internal and external information (message of communication) means and measures (Schmidt 1995, Cornelissen 2008). The collective message from both sources (Haynes 1990) conveys an organization identity (Gray \& Balmer 1998) through every form, manner and medium of communications to the respective stakeholders. A stakeholder is defined as anyone who has a stake in the organization's success. These include vendors, customers, employees and executive of the organization (Goodman 2000).

\section{STRATEGIC MANAGEMENT PERSPECTIVE}

As mentioned before, corporate communication is a vital instrument of the organization to gain a competitive advantage in corporate setting. Organization can't execute strategy to their stakeholder without communication. Therefore, corporate communication is important tools and activities for disseminating corporate strategies for the companies (Fleisher 1998). As indicates by Forman \& Argenti (2005), business communication scholar has become progressively more interested in the involvement of corporate communication to an ability of the company to create and disseminate strategy. For example, Rindova \& Fombrum (1999) had conclude the linked between strategy and communication were established the competitive advantage by creating desired outcomes through material resources and managing the communication. While, Botan (1997) has found the strategic communication campaign of the company can helps to build ethical relationships between the company and its key stakeholder. Therefore, corporate communication can be perceived as an important competitive instrument to support the organization in its pursuit of strategic objectives and goals.

Moreover, Forman \& Argenti (2005) also found 'the corporate communication function was tightly connected to strategy implementation in some case. The elements of strategic can be found from the integration of three form of communication. Firstly, management communication related to both internal and external stakeholder; second, marketing communications in relation to advertising and selling; and third, organizational communication such as internal media and public relations (Stainer \& Stainer 1997). The company can create competitive advantage by socializing its stakeholder to its own culture and use communication strategy to form long-term relationships with the stakeholders in shaping the organization's image and reputation (Rindova \& Fombrun 1999).

Previous literature identifies a link between the corporate communication function and stakeholder focussed strategy. Yamauchi (2001) identifies a close link between corporate communication and corporate strategy; indeed Forman \& Argenti (2005) assert using a corporate communication is a management strategy because it involves determining which stakeholder is important, and what information they need. Yamauchi further argues that anticipated responses to communication with stakeholders inform management strategy. Similarly, Varey \& White (2000) advocate using a corporate communication to create a dialogue with stakeholder in order to gain a better understanding of their interests. 
It has been found that corporate communication is theoretically associated with implementing strategy and building company's reputation and brand (Fombrun 1996). Melewar \& Karaosmanoglu (2006) indicate that the communication processes and activities are important to achieve a favourable public exposure towards company's core ideology. If companies can constantly perform well in sustaining a consistent image over the years, they can achieve a favourable reputation (Fombrun \& Shanley 1990). Furthermore, Argenti \& Druckenmiller (2004) argue that careful management of the corporate brand can enhance the reputation by guiding and stimulating a company's actions and keeping management focused on strategy implementation.

On the other hand, Varey (1997) believed that future corporate communication would get proper recognition as strategic issues which commensurate support, through board-level representation. Managed communication activities must be looked at as key business function and investment opportunity, and it has a place in the decision making process throughout one's business. It is not just having an information dissemination role. Therefore, to play a strategic role, there are five challenges, in the current development of corporate communication functions that include (1) new sophistication in customers, or audience; (2) new media technologies; (3) more widespread ethical environment; (4) stronger economic factors; and (5) new strategic alliance (Goodman 2000). Hence, the corporate communication function has come to be increasingly significant and Gilder (1982) suggested effective communication managers should be at the forefront of strategic planning to help their organizations survive. In addition, Cornelissen (2008) believed the complex nature of corporate communication, especially in organizations with a wide geographical, range, such as multinational firms, or with a wide range of products or services, need to be balanced by communication coordination through strategic management planning.

\section{CONCLUSION}

Corporate communication is a complex concept (Christensen et al. 2007). It has been variously defined and used interchangeably with related concepts in different areas (Wright 1997, MacNamara 2006). Moreover, corporate communication is an important factor for the strategic management to gain a competitive advantage in corporate setting. Communication executes a strategy to organization's' stakeholder. Therefore, corporate communication is important tools and activities for disseminating corporate strategies for the companies.

\section{REFERENCES}

Argenti, P.A. 1996. Corporate communication as a discipline: toward a definition. Management Communication Quarterly 10(1): 73-98.

Argenti, P.A. 1998. Strategic employee communication. Human Resources Management 37(3/4): 199-206.

Argenti, P.A. 2000. Branding b-schools: reputation management for MBA programs. Corporate Reputation Review 3(2): 171-178.

Argenti, P.A. \& Druckenmiller, B. 2004. Reputation and the Corporate Brand. Corporate Reputation Review 6(4): 368374.

Botan, C. 1997. Ethics in strategic communication campaigns: The case for a new approach to public relations. Journal of Business Communication 34(2): 188-202.

Christensen, L.T., Cornelissen, J.P. \& Morsing, M. 2007. Corporate communications and its receptions: a comment on Llewellyn and Harrison. Human Relations 60(4): 653-661.

Cornelissen, J.P. 2008. Corporate Communication: a Guide to Theory and Practice 2nd Edition. London: Sage Publications Ltd.

Fleisher, C.S. 1998. A benchmarked assessment of the strategic management of corporate communications. Journal of Marketing Communications 4: 163-176.

Fombrun, C. 1996. Reputation: Realizing value from corporate image. Boston: Harvard Business School Press.

Fombrun, C. \& Shanley, M. 1990. What's in a name? reputation building and corporate strategy. Academy of Management Journal 33(2): 233-258.

Forman, J. \& Argenti, P.A. 2005. How corporate communication influences strategy implementation, reputation and the corporate brand: An Exploratory Qualitative Study. Corporate Reputation Review 8(3): 245-264.

Gilder, J.A. 1982. Strategic planning role beckons thinking communicators. Journal of Communication Management 11: $9-11$

Goodman, M.B. 2000. Corporate communication: the american picture. Corporate Communications: An International Journal 5(2): 69-74.

Gray, E.R. \& Balmer, J.M.T. 1998. Managing corporate image and corporate reputation. Long Range Planning 31(5): 695702.

Grunig, J. \& Hunt, T. 1984. Management Public Relations. New York: Winston.

Haynes, L. 1990. Corporate communications: marketing dossier positive vibes. Marketing 21: 29-30.

Macnamara, J. 2006. PR metrics: research for planning and evaluation of $P R$ and corporate communication, research paper. Australia: Media Monitors Pty Ltd.

Melewar, T.C. \& Karaosmanoglu, E. 2006. Corporate branding, identity and communications: A contemporary perspective. The Journal of Brand Management 14(1-2): 1-4.

Rindova, V.P. \& Fombrun, C.J. 1999. Constructing competitive advantage: the role of firm-constituent interaction. Strategic Management Journal 20(8): 691-710.

Schmidt, K. 1995. The Quest for Identity. London: Cassell.

Stainer, A. \& Stainer, L. 1997. Productivity and performance dimensions of corporate communications strategy. Corporate Communications: An International Journal 2(2): 7075 . 
Van Riel, C.B.M. 1995. Principles of Corporate Communication. New Jersey: Prentice-Hall.

Van Riel, C.B.M. \& Fombrun, C.J. 2007. Essentials of Corporate Communication. New York: Routledge.

Varey, R.J. 1997. A picture of corporate communications management in the UK. Corporate Communications: An International Journal 2(2): 59-69.

Varey, R.J. 1998. Locating marketing within the corporate communication managing system. Journal of Marketing Communications 4(3): 177-190

Varey, R.J. \& White, J. 2000. The corporate communication system of managing. Corporate Communications: An International Journal 5(1): 5-11.

Welch, M. \& Jackson, P.R. 2007. Rethinking internal communication: a stakeholder approach. Corporate Communication: An International Journal 12(2): 177-198.

Wright, D.K. 1997. Perceptions of corporate communication as public relations. Corporate Communications: An International Journal 2(4): 143-154.

Yamauchi, K. 2001. Corporate communication: a powerful tool for stating corporate missions. Corporate Communications: An International Journal 6(3): 131-136. 